Sains Malaysiana 46(1)(2017): 27-34

http://dx.doi.org/10.17576/jsm-2017-4601-04

\title{
Representing Landslides as Polygon (Areal) or Points? How Different Data Types Influence the Accuracy of Landslide Susceptibility Maps
}

(Mempersembahkan Tanah Runtuh dalam Bentuk Poligon (Luas) atau Titik? Bagaimana Jenis Data Berbeza Mempengaruhi Ketepatan Peta Kecenderungan Tanah Runtuh)

\author{
Norbert Simon*, MAIREAd De RoIste, MichaEl CrozIER \& AbDUl GHANi RAFEK
}

\begin{abstract}
In the literatures, discussions on the accuracy of different models for landslide analysis have been discussed widely. However, to date, arguments on the type of input data (landslides in the form of point or polygon) and how they affect the accuracy of these models can hardly be found. This study assesses how different types of data (point or polygon) applied to the same model influence the accuracy of the model in determining areas susceptible to landsliding. A total of 137 landslides was digitised as polygon (areal) units and then transformed into points; forming two separate datasets both representing the same landslides within the study area. These datasets were later separated into training and validation datasets. The polygon unit dataset uses the area density technique reported as percentage, while the point data uses the landslide density technique, as means of assigning weighting to landslide factor maps to generate the landslide susceptibility map that is based on the analytical hierarchy process (AHP) model. Both data groups show striking differences in terms of mapping accuracy for both training and validation datasets. The final landslide susceptibility map using area density (polygon) as input only has 48\% (training) and 35\% (validation) accuracy. The accuracy for the susceptibility map using the landslide density as input data achieved $89 \%$ and $82 \%$ for both training and validation datasets, respectively. This result showed that the selection of the type of data for landslide analysis can be critical in producing an acceptable level of accuracy for the landslide susceptibility map. The authors hope that the finding of this research will assist landslide investigators to determine the appropriateness of the type of landslide data because it will influence the accuracy of the final landslide potential map.
\end{abstract}

Keywords: AHP; Geographic Information System (GIS); landslide; landslide density; landslide susceptibility map

\section{ABSTRAK}

Kajian lepas telah banyak membincangkan kejituan model tanah runtuh yang berlainan. Walau bagaimanapun, sehingga sekarang, perbincangan mengenai jenis data (tanah runtuh dalam bentuk titik atau poligon) dan bagaimana jenis data ini mempengaruhi kejituan model-model tanah runtuh ini agak sukar untuk ditemui. Kajian ini menilai bagaimana pelbagai jenis data (titik atau poligon) mempengaruhi ketepatan model dalam menentukan kawasankawasan yang cenderung untuk mengalami tanah runtuh. Sebanyak 137 tanah runtuh telah didigitkan sebagai unit poligon (keluasan) dan data yang sama ini kemudiannya diubah kepada data titik; membentuk dua set data yang berasingan dengan kedua-duanya mewakili tanah runtuh yang sama dalam kawasan kajian. Set data ini kemudiannya dibahagikan kepada set latihan dan set penentusahan. Unit data poligon menggunakan teknik ketumpatan keluasan dan dilaporkan dalam bentuk peratusan, manakala data titik menggunakan teknik ketumpatan tanah runtuh (frekuensi) sebagai kaedah untuk menentukan pemberat dalam peta faktor tanah runtuh yang kemudiannya digunakan untuk menjana peta kecenderungan tanah runtuh berasaskan model Proses Analisis Hierarki (AHP). Kedua-dua kumpulan data ini menunjukkan perbezaan yang ketara daripada segi ketepatan pemetaan untuk set data latihan dan penentusahan. Peta kecenderungan tanah runtuh yang menggunakan ketumpatan kawasan (poligon) sebagai input hanya mempunyai ketepatan $48 \%$ dan 35\% masing-masing untuk set data latihan dan pengesahan. Manakala ketepatan peta kecenderungan yang menggunakan ketumpatan tanah runtuh (titik) sebagai data input mencapai $89 \%$ dan $82 \%$ untuk kedua-dua set data latihan dan penentusahan. Keputusan ini menunjukkan bahawa pemilihan jenis data untuk analisis tanah runtuh adalah kritikal dalam menghasilkan peta kecenderungan tanah runtuh pada tahap ketepatan yang boleh diterima. Penulis berharap hasil kajian ini dapat membantu para pengkaji tanah runtuh untuk memastikan kesesuaian jenis data yang digunakan kerana pemilihan jenis input data tersebut akan mempengaruhi hasil akhir peta potensi tanah runtuh yang dihasilkan.

Kata kunci: AHP; ketumpatan tanah runtuh; peta kecenderungan tanah runtuh; Sistem Maklumat Geografi (GIS); 
tanah runtuh

\section{INTRODUCTION}

Either point or polygon (area) representations are most appropriate for landslide susceptibility mapping has not been discussed in the past literatures. Often, discussions on landslide analysis focus more on the material behaviours of slope, type of models (e.g. statistic, heuristic and deterministic) and the benefits of using GIS for landslide studies (Budetta et al. 2008; Gahgah et al. 2009; Goh et al. 2014, 2011; Jaiswal et al. 2010; JTC-1 2008; Komac 2006; Lin et al. 2010; Matthew et al. 2007; Melchiorre et al. 2008; Poudyal et al. 2010; Rafek et al. 2012; Yalcin 2008; Yang \& Yeh 2015). Each model has its own approach and therefore, it is difficult to compare the extent to which model differences affect success.

However, for a given model, it is possible to compare the influence of different input factors and their manner of representation on model output. This study analyses how the representation of landslides as either points or polygon (areal) units applied within the same model may affect the ability of the model to identify susceptible areas. The principal hypothesis is that the way in which input data is represented affects mapping accuracy. To date, this issue has been given little attention in the literature concerning landslide modelling using Geographic Information System (GIS).

\section{DESCRIPTION OF THE STUDY AREA}

The study area is located in the west coast region of Sabah, Malaysia. The study area includes the state capital of Sabah (Kota Kinabalu) and several smaller towns such as Menggatal, Telipok and Tuaran. It covers an area of $387 \mathrm{~km}^{2}$ involving four adjacent 1:50,000 topographic maps (Figure 1).

The Crocker Formation which formes the Crocker Range is a substantial formation that consists of shale, thick sandstone and interbedded sandstone-shale units (Roslee et al. 2006). The sandstone unit is characterised by angular to sub-rounded quartz grains and has a thickness ranging from a few centimeters to several meters (Faisal et al. 1999; Tongkul 2007). The shale, on the other hand, is a fine grained rock usually grey in colour but red shale can be observed in certain locations (Tongkul 2007). The Crocker Formation has experienced intense deformation that results in tight folds and thrust faults and the argillaceous layers commonly show sign of shearing, fracturing and jointing (Faisal et al. 1999; Tongkul 2007).

\section{METHODS}

\section{LANDSLIDE INVENTORY MAP}

A landslide inventory was created from a set of 1: 10,000 aerial photographs taken in 2010 . The landslide inventory is used to store the information on the landslides, in particular the location and areal extent of each landslide. It was also used to generate and assess the accuracy of the final landslide susceptibility maps produced in this study. Landslides from aerial photographs were identified based on the criteria for landslide identification provided by Ho et al. (2010), Rib and Ta (1978) and van Westen and Soeters (1996). A total of 137 landslides that are clearly visible were identified from the aerial photographs.

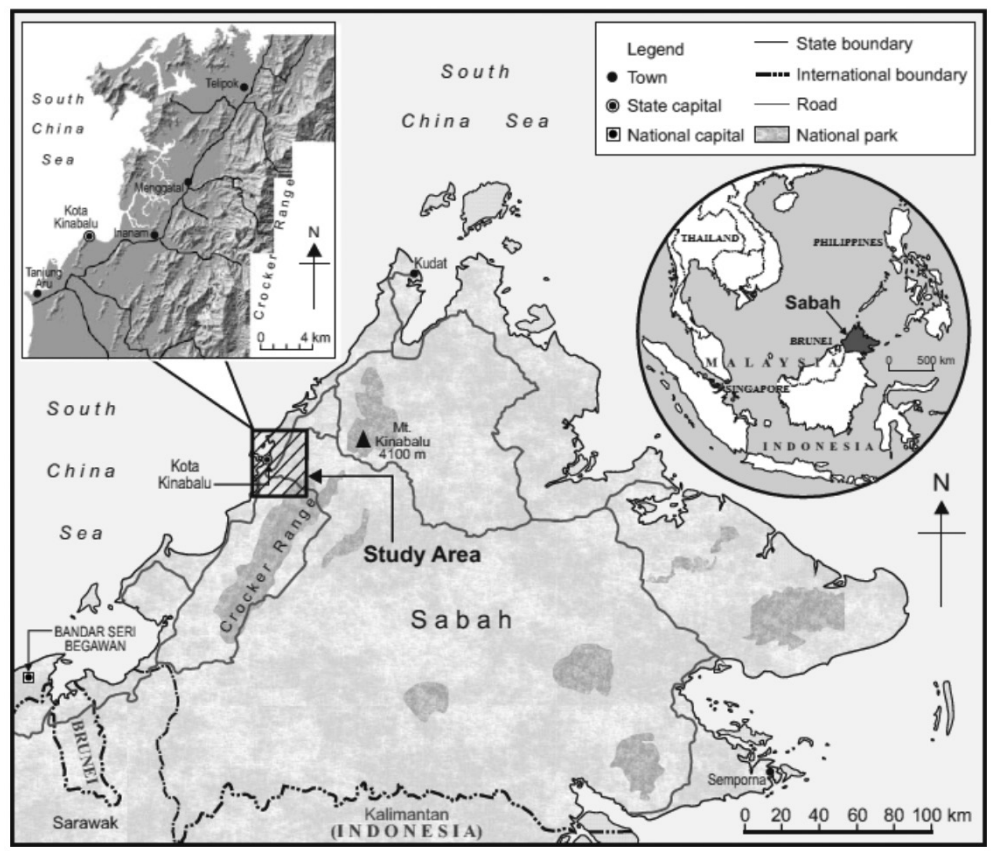

FIGURE 1. Study area. Inset map shows the location of the study area on the west coast of Sabah 


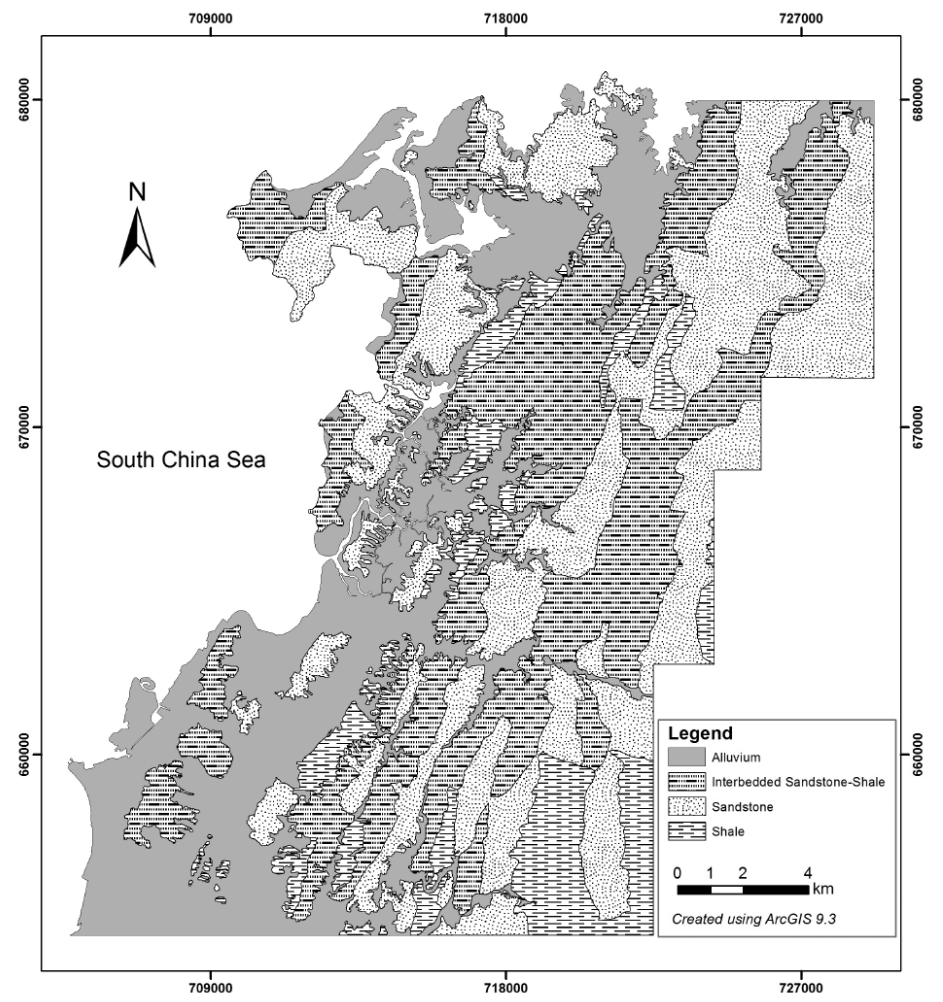

FIGURE 2. Lithology of the study area

TYPES OF DATA INPUT: AREA DENSITY AND LANDSLIDE DENSITY

The landslide data used for the modelling is of two types: areal units and points. The landslides obtained from the landslide inventory were originally digitised as areal features. These landslide features were later transformed into points using the area based technique. In the process of developing a susceptibility model, the degree of association between landslide location (represented either by point or area) and various landslide factors is determined. Landslide factors are represented by classes; e.g., slope classes are defined by slope angle such as $<15,15-2526-35$ and $>$ 35 degrees. The method for assigning weights to each landslide factor class is different for each data type. In the case of landslides represented as areal units, weighting is determined by intersecting the landslide with the classes of each landslide factor. The landslide area that occupies each factor class is divided by the area of that class. This will result in landslide area density for that particular class, reported as a percentage. The calculation technique for the area density is shown in (1).

Area density $=($ Landslide area/area occupied by the factor class) $\times 100$.

For landslides represented as points, calculation of landslide density for a particular landslide factor class follows the technique designed by Hufschmidt and Crozier (2008). The number of landslides in each factor class is divided by the area occupied by the factor class. The calculation technique is shown in (2).

$$
\begin{aligned}
\text { Landslide density }= & \text { Number of landslides } / \\
& \text { area occupied by the } \\
& \text { factor class. }
\end{aligned}
$$

Both of the landslide datasets (point and area) were separated into two groups. This separation was done before transforming the landslide area to point to ensure both datasets have the same numbers and locations of landslides. The first group is known as the training dataset and the second as validation dataset. Both datasets were randomly separated using the geostatistical tool in ArcGIS 9.3. The training dataset is used to generate the landslide susceptibility map and the validation dataset is used to measure the performance of the landslide susceptibility model. The ratio of both datasets is around 50:50 with 69 and 68 landslides in the training and validation datasets, respectively.

\section{SELECTION OF DATA LAYERS}

The data layers in this study were generated from aerial photographs, satellite images and topographic maps. The landslide inventory map serves a fundamental role in this study where it is used with the landslide factors to generate the landslide susceptibility map as well as for accuracy assessment. There were 6 landslide factors used for this study, these factors were slope angle, slope aspect, lithology, road density, lineament density and elevation. These are all factors that have been shown in the literature to influence the spatial occurrence of landslides (Dai et al. 2002; Dhakal et al. 1999; Eyles et al. 1978; Lee \& Talib 2005). 


\section{THE ANALYTICAL HIERARCHY PROCESS MODEL (AHP)}

Analytical Hierarchy Process (AHP) is a multi-criteria decision making approach, where factors are arranged in a hierarchical structure (Saaty 1994). AHP is a method of obtaining the degree of importance of factors in a decision making process through pairwise comparison (Saaty 2008). The AHP technique uses a scale of 1 to 9 to compare the degree of influence by different factors toward an event. Comparison between factors involves a pariwise matrix where the degree of two factors can be compared. The degree of importance for each factor is indicated by an eigen value obtained from the pairwise comparison. However, one should note that the consistency ratio of a pairwise matrix must not exceed 0.1 or otherwise the matrix must be revised (Guidi et al. 2009; Komac 2006). Based on the AHP equation (Saaty 1994), the equation to construct the landslide susceptibility map is

$$
\begin{aligned}
& \text { Landslide } \quad=\mathrm{B}_{1} \mathrm{~m}_{1}+\mathrm{B}_{2} \mathrm{~m}_{2}+ \\
& \text { susceptibility Map } \quad \mathrm{B}_{3} \mathrm{~m}_{3}+\ldots+. \mathrm{B}_{\mathrm{n}} \mathrm{m}_{\mathrm{n}} \text {, }
\end{aligned}
$$

where $B$ is the eigen value obtained from the pairwise matrix and $m$ represents the landslide factor.

\section{ACCURACY ASSESSMENT TECHNIQUE}

This study uses the degree of fit technique to measure the accuracy of the landslide susceptibility map. This technique measures the percentage of landslides that fall into each susceptibility category (Fernandez et al. 2003; Peralvarez et al.2009). The higher the percentage of landslides found in the 'high' to 'very high' susceptibility categories, the higher the accuracy of the landslide susceptibility map (Fernandez et al. 2003).

\section{RESULT AND DISCUSSION}

\section{PAIRWISE MATRIX}

The pairwise matrix for the AHP model is given in Table 1 . From the pairwise matrix, the eigen value for each factor was calculated. From the eigen value, it is indicated that the road density is the most important landslide inducing factor followed by slope angle, elevation, lithology, slope aspect and lineament density.
The equation to generate the landslide susceptibility using the eigen value for each landslide factor is presented as:

$$
\begin{aligned}
\text { Landslide } & \\
\text { Susceptibility Map }= & 0.2673 * \text { road density }+ \\
& 0.2585 * \text { slope angle }+ \\
& 0.1711 * \text { elevation }+ \\
& 0.1707 * \text { lithology }+ \\
& 0.0837 * \text { slope aspect }+ \\
& 0.0487 * \text { lineament density. }
\end{aligned}
$$

\section{WEIGHTING OF LANDSLIDE FACTOR CLASSES}

The weighting for each of the landslide factor class for each data type (points or area) was calculated based on the area and landslide density techniques. The level of susceptibility for each landslide factor's class is given in Table 2. These weighting is used together with the eigen value from the pairwise matrix to generate the final landslide susceptibility map.

\section{LANDSLIDE SUSCEPTIBILITY MAP}

The landslide susceptibility maps generated based on the AHP model for both area density (AHP_Area) and landslide density (AHP_Ld) is shown in Figure 3. A comparison of the two maps shows that the pattern of susceptibility classes is clearly different. As shown in Figure 3, high susceptibility class in the AHP_area is concentrated in the southwest, centre and eastern parts of the study area. These areas are lowland areas with less mountainous landscape, except in the eastern part. In contrast to the AHP_area map, the AHP_Ld map indicates the southwest and centre areas as low susceptibility areas. The high susceptibility class is mostly distributed in mountainous terrain. The percentage of area covered by each susceptibility class for both maps is shown in Figure 4.

Both maps showed similar pattern in terms of the distribution of susceptibility areas from low to high. However, the AHP_Ld indicates that the study area has more high susceptibility area than the AHP_area's map. The moderate susceptibility class also covers a larger area in the AHP_Ld map compared to the AHP_area map. This demonstrates that the AHP_Ld indicates that the study area has a greater area susceptible to landsliding and the AHP_area was unable to identify these locations.

TABLE 1. Pairwise matrix for the AHP landslide susceptibility model

\begin{tabular}{lccccccc}
\hline Factor & SAng & Sh & Sa & Lith & Line & Rd & Eigen value \\
\hline SAng & 1 & 3 & 3 & 1 & 4 & 1 & 0.2637 \\
Elev & $1 / 3$ & 1 & 3 & 1 & 3 & 1 & 0.2585 \\
Sa & $1 / 3$ & $1 / 3$ & 1 & $1 / 3$ & 3 & $1 / 3$ & 0.1711 \\
Lith & 1 & 1 & 3 & 1 & 3 & $1 / 3$ & 0.1707 \\
Line & $1 / 4$ & $1 / 3$ & $1 / 3$ & $1 / 3$ & 1 & $1 / 5$ & 0.0837 \\
Rd & 1 & 1 & 3 & 3 & 5 & 1 & 0.0487 \\
\hline
\end{tabular}

Notes: Slope angle (SAng), elevation (elev), slope aspect (Sa), lithology (Lith), lineament density (Line), road density $(R d)$ 
TABLE 2. Landslide factors and weighting for each factor's class based on the area and landslide density techniques

\begin{tabular}{|c|c|c|c|c|c|c|}
\hline Landslide factors & Class & $\begin{array}{l}\text { Landslide } \\
\text { frequency }\end{array}$ & $\begin{array}{l}\text { Landslide area } \\
\qquad\left(\mathrm{m}^{2}\right)\end{array}$ & $\begin{array}{c}\text { Total area for } \\
\text { classes }\left(\times 10^{6} \mathrm{~m}^{2}\right.\end{array}$ & $\begin{array}{l}\text { Area density } \\
\qquad(\%)\end{array}$ & $\begin{array}{c}\text { Landslide } \\
\text { density }\end{array}$ \\
\hline \multirow[t]{4}{*}{ Slope angle $\left(^{\circ}\right)$} & $<15$ & 16 & 27247 & 236.92 & 7 & 0.07 \\
\hline & $15-25$ & 33 & 53605 & 99.46 & 34 & 0.33 \\
\hline & $25-35$ & 19 & 25207 & 44.69 & 36 & 0.43 \\
\hline & $>35$ & 1 & 2263 & 6.53 & 22 & 0.15 \\
\hline \multirow[t]{4}{*}{ Elevation (m) } & $<30$ & 24 & 15449 & 174.67 & 6 & 0.14 \\
\hline & $30-60$ & 23 & 36253 & 47.43 & 48 & 0.48 \\
\hline & $60-90$ & 5 & 11673 & 27.93 & 26 & 0.18 \\
\hline & $>90$ & 17 & 44947 & 138.76 & 20 & 0.12 \\
\hline \multirow[t]{9}{*}{ Slope aspect } & Flat (F) & 16 & 22583 & 209.62 & 3 & 0.08 \\
\hline & $\mathrm{N}$ & 6 & 12175 & 22.59 & 14 & 0.27 \\
\hline & $\mathrm{NE}$ & 7 & 6128 & 19.03 & 8 & 0.37 \\
\hline & $\mathrm{E}$ & 5 & 3599 & 19.93 & 5 & 0.25 \\
\hline & $\mathrm{SE}$ & 4 & 4862 & 18.99 & 7 & 0.21 \\
\hline & $\mathrm{S}$ & 8 & 15815 & 19.33 & 21 & 0.41 \\
\hline & SW & 9 & 19646 & 22.30 & 22 & 0.40 \\
\hline & $\mathrm{W}$ & 4 & 6942 & 28.60 & 6 & 0.14 \\
\hline & NW & 10 & 16572 & 28.25 & 15 & 0.35 \\
\hline \multirow[t]{5}{*}{ Lithology } & Alluvium & 2 & 2035 & 109.65 & 2 & 0.02 \\
\hline & Interbedded & & & & & \\
\hline & sandstone-shale & 29 & 69140 & 92.09 & 68 & 0.31 \\
\hline & Sandstone & 31 & 33002 & 147.58 & 20 & 0.21 \\
\hline & Shale & 7 & 4144 & 39.32 & 10 & 0.18 \\
\hline \multirow{3}{*}{$\begin{array}{l}\text { Lineament density } \\
\left(\mathrm{m} / 40,000 \mathrm{~m}^{2}\right)\end{array}$} & $<50$ & 54 & 73497 & 311.43 & 20 & 0.17 \\
\hline & $50-150$ & 8 & 19567 & 30.12 & 54 & 0.27 \\
\hline & $>150$ & 7 & 15257 & 47.09 & 27 & 0.15 \\
\hline Road density & $<50$ & 16 & 39102 & 218.90 & 10 & 0.07 \\
\hline \multirow[t]{2}{*}{$\left(\mathrm{m} / 40,000 \mathrm{~m}^{2}\right)$} & $50-150$ & 8 & 24614 & 32.38 & 41 & 0.25 \\
\hline & $>150$ & 45 & 123566 & 137.36 & 49 & 0.33 \\
\hline
\end{tabular}

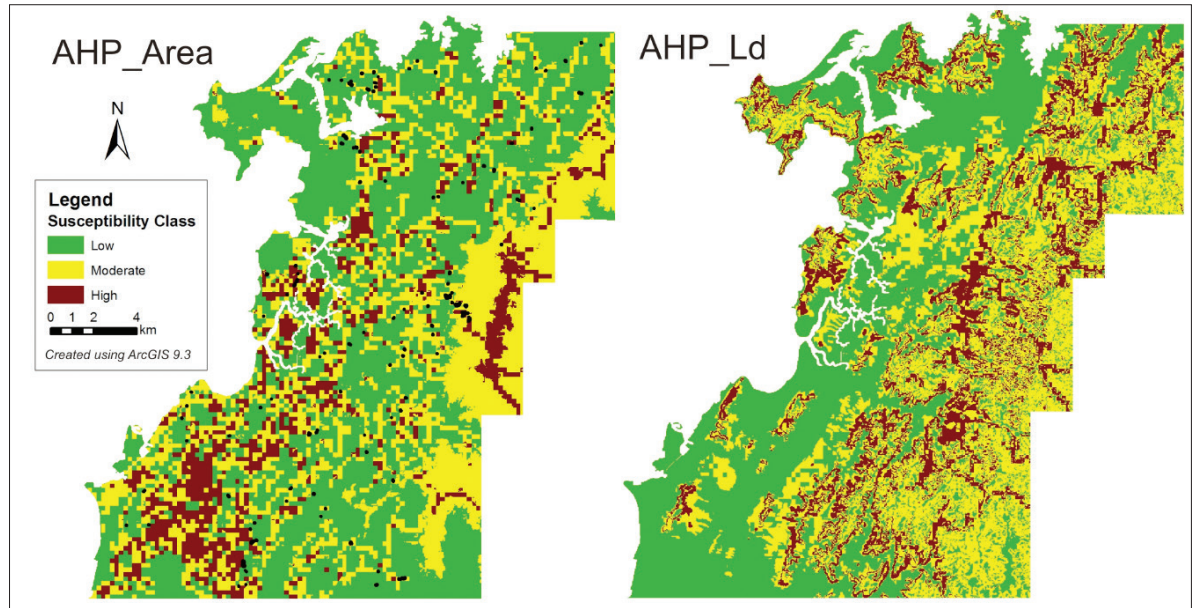

FIGURE 3. Landslide susceptibility maps for AHP_area (left) and AHP_Ld (right)

MAP ACCURACY

The results of the accuracy assessment is separated into two components: Training and validation datasets. As mentioned earlier, the training dataset is used to create both the AHP_area and AHP_Ld landslide susceptibility maps and the validation dataset is used to test the accuracy of both maps. The accuracy of both maps for the training and validation datasets are given in Figure 5.

The training and validation dataset showed that the AHP_Ld has higher accuracy than the AHP_area. The AHP_Ld is capable of classifying $89 \%$ of the landslides in the training dataset into its high susceptibility class as 


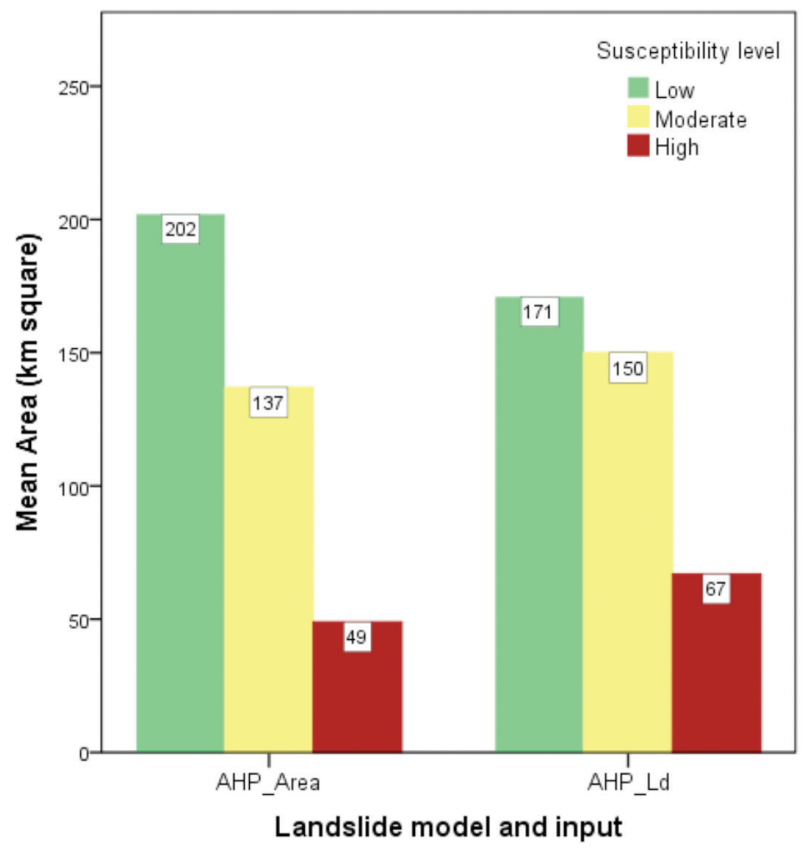

FIGURE 4. Area for each landslide susceptibility class for the AHP_area and AHP_Ld landslide susceptibility maps

opposed to only $48 \%$ by the AHP_area. In terms of the validation dataset, $82 \%$ of landslides were classified in the high susceptibility class by AHP_Ld and only $35 \%$ by the AHP_area. The reason that the AHP_Ld model is more effective in mapping landslides than the AHP_area model is because it narrows down the area considered as highly susceptible to landslides. Although it has more area classified as highly susceptible to landslides compared to the AHP_area, it identifies the affected area correctly. If the high susceptibility class of the AHP_Ld model is intersected with the landslides area, the AHP_Ld model correctly categorised a higher landslide area than the AHP_area model (Table 3).

Looking at the pattern of landslide areas classified in each of the models' classes, the AHP_area classified most the areas actually affected by landslides in the validation dataset into the moderate susceptibility class and less in the high susceptibility class. The AHP_Ld however, captured higher actual landslide areas in its high susceptibility class and fewer in the moderate and low susceptibility classes. The result shown in Table 3 indicates that the AHP_Ld model performed better than the AHP_area model in capturing correctly the landslide area. Although the AHP_Ld has more high susceptibility area than the AHP_area model, the difference of area is only $18 \mathrm{~km}^{2}$, which is relatively small.

This study found that several reasons contributed to the higher accuracy of the landslide density technique. First, conversion from raster to vector can remove smaller landslides from the analysis when using an area based technique. The landslide analysis was in raster based in this study using a $30 \times 30 \mathrm{~m}$ cell size. This means that any landslide smaller than $30 \times 30 \mathrm{~m}$ will disappear during the conversion process. In contrast, the number of landslides represented as points remain constant when the data are converted to raster. In this study, 15 landslides areas were automatically removed when the digitised landslide layer was converted to raster due to their small size. The cell size limitation is related to the medium scale map $(1: 50,000)$ used for this study.
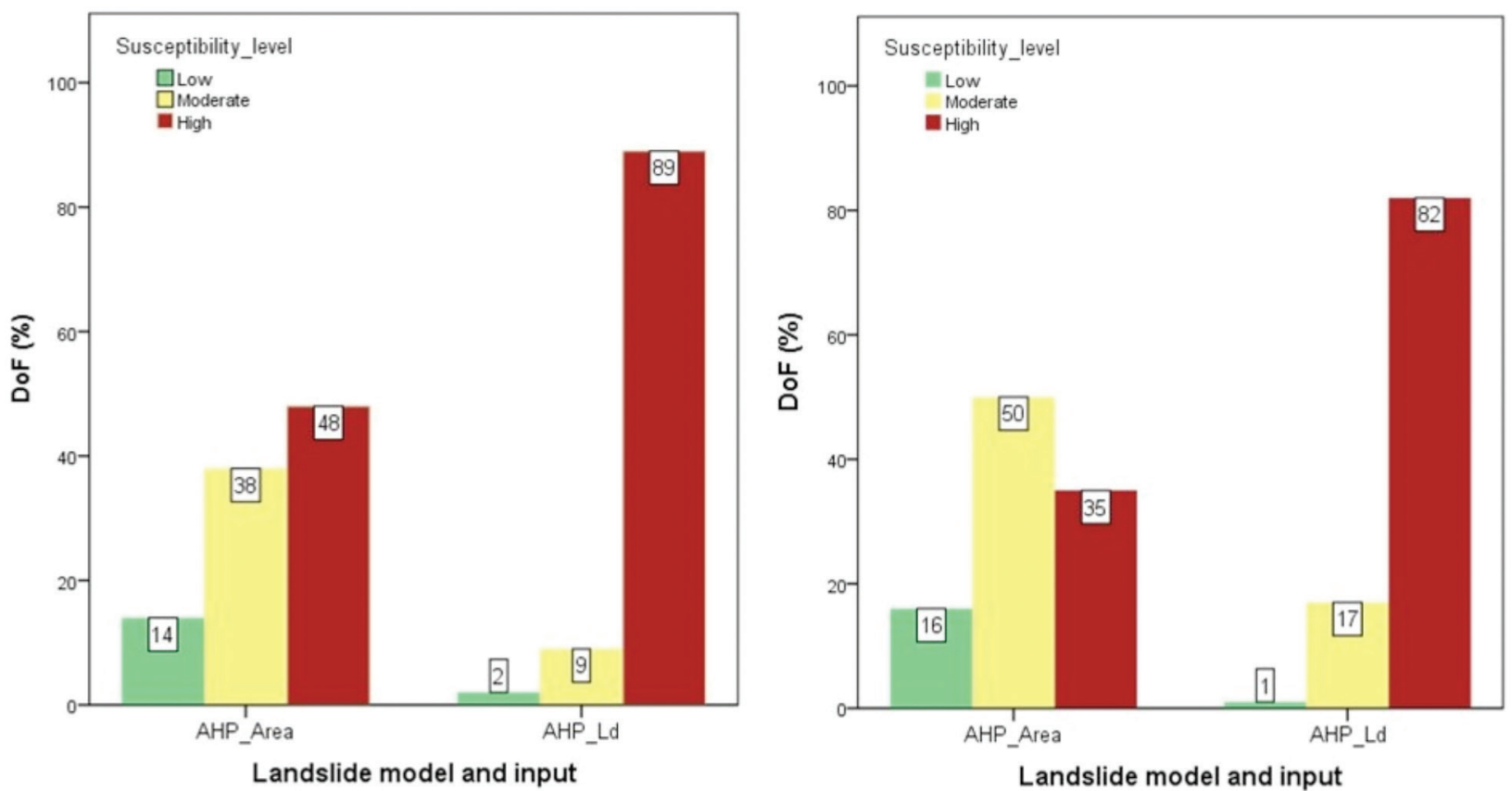

FIGURE 5. Accuracy result for the AHP_area and AHP_Ld models (a) Accuracy of the susceptibility map based on the training dataset, (b) accuracy of the susceptibility map based on the validation dataset 
TABLE 3. Landslide area recorded in each AHP_area and AHP_Ld susceptibility class

\begin{tabular}{lcccc}
\hline \multirow{2}{*}{ Susceptibility class } & \multicolumn{3}{c}{ Area of actual landslides in each category $\left(\mathrm{m}^{2}\right)$} \\
\cline { 2 - 5 } & Training & Validation & Training & AHP_Ld \\
\cline { 2 - 5 } & 29,242 & 21,597 & 3,614 & 2,415 \\
\cline { 2 - 5 } Low & 54,553 & 46,123 & 19,447 & 23,842 \\
Moderate & 24,527 & 11,573 & 85,260 & 53,035 \\
High & &
\end{tabular}

Second, when a landslide area is converted to raster, the shape of the area will change resulting in additional inaccuracies. The raster layer is heavily related to the cell size and where the landslide does not fill the majority of the cell, its area is reduced to the cells where is in the majority. This means that for some landslide the area is reduced. When intersected with the landslide factors, the reduced landslide area will provide inaccurate information on the level of susceptibility in certain factor classes. This may under-represent the influence of some potentially important landslide factors. This inaccurate representation of the landslide area will greatly impact the accuracy of the final landslide susceptibility map. However, in some cases, such as in this study, conversion of the landslide areas to raster format is necessary due to comparison with the mainly raster based landslide factors maps (e.g. slope).

Due to the errors mentioned, this study suggested that using the landslide density is a suitable approach when analysing landslides in a low to medium resolution mapping with map scale smaller than 1: 50,000. As demonstrated in this study, representing landslides as points can minimize loss of information due to data conversion from vector to raster. However, one limitation of using points to represent landslide locations and for analysis is that it excludes the landslide area completely.

\section{CONCLUSION}

This study successfully demonstrates that one of the major factors that control the accuracy of a model is the selection of data type, namely, areal or point. As evident in this study, the choice of data input greatly influences the accuracy of a model in producing a good landslide susceptibility map. A higher accuracy of landslide susceptibility mapping was achieved when using points as the data input (AHP_Ld) compared to the area type data (AHP_area).

\section{ACKNOWLEDGEMENTS}

This research was funded by Fundamental Research Grant Scheme (FRGS/1/2014/STWN06/UKM/03/1) and the University Research Grant (GUP-2014-031) under the Ministry of Education, Malaysia and the National University of Malaysia, respectively.

\section{REFERENCES}

Budetta, P., Santo, A. \& Vivenzio, F. 2008. Landslide hazard mapping along the coastline of the Cliento region (Italy) by means of a GIS-based parameter rating approach. Geomorphology 94: 340-352.

Dai, F.C., Lee, C.F. \& Ngai, Y.Y. 2002. Landslide risk assessment and management: An overview. Engineering Geology 64: 65-87.

Dhakal, A.S., Amada, T. \& Aniya, M. 1999. Landslide hazard mapping and the application of GIS in the Kulekhani watershed, Nepal. Mountain Research and Development 19(1): 3-16.

Eyles, R.J., Crozier, M.J. \& Wheeler, R.H. 1978. Landslips in Wellington City. New Zealand Geographer 34: 58-74.

Faisal, M.M., Tahir, S.H. \& Edward, V.L.Z. 1999. Landslides along the Kota Kinabalu-Tambunan road. Second Asian Symposium on Engineering Geology and the Environment. Bangi: IAEG Malaysian National Group.

Fernandez, T., Irigaray, C., Hamdouni, R.E. \& Chacon, J. 2003. Methodology for landslide susceptibility mapping by means of a GIS: Application to the Contraviesa area (Granada, Spain). Natural Hazards 30: 297-308.

Gahgah, M.M.,Akhir, J.M., Rafek, A.G.M. \& Abdullah, I. 2009. GIS based assessment on landslide hazard zonation: Case study of Cameron Highlands - Gua Musang road Kelantan, Malaysia. Sains Malaysiana 38(6): 827-833.

Goh, T.L., Rafek, A.G. \& Arifin, M.A. 2014. Correlation of joint roughness coefficient with peak friction angles of discontinuity planes of granite, Peninsular Malaysia. Sains Malaysiana 43(5): 751-756.

Goh, T.L., Rafek, A.G., Ariffin, M.H. \& Yunus, B.N. 2011. Direct shear test of granite discontinuity plane surface. Sains Malaysiana 40(5): 419-423.

Guidi, G., Gugliermetti, F. \& Violante, A.C. 2009. Application of AHP method in selection of best available techniques for oil spill containment and clean-up. AIDIC Conference Series 9. pp. 159-166.

Ho, H.J., Lee, S. \& Soedradjat, G.M. 2010. Quantitative landslide susceptibility mapping at Pemalang area, Indonesia. Environ. Earth Sci. 60: 1317-1328.

Hufschmidt, G. \& Crozier, M.J. 2008. Evolution of natural risk: Analysisng changing landslide hazard in Wellington, Aotearoa/New Zealand. Natural Hazards 45: 255-276.

Jaiswal, P., van Westen, C.J. \& Jetten, V. 2010. Quantitative landslide hazard assessment along a transportation corridor in southern India. Engineering Geology 116: 236-250.

JTC-1. 2008. Guidelines for landslide susceptibility, hazard and risk zoning for land use planning. In Engineering Geology, edited by Fell, R., Corominas, J., Bonnard, C., Cascini, L., Leroi, E. \& Savage, W.Z. 102(3-4): 85-98. 
Komac, M. 2006. A landslide susceptibility model using the analytical hierarchy process method and multivariate statistics in perialpine Slovenia. Geomorphology 74: 17-28.

Lee, S. \& Talib, J.A. 2005. Probabilistic landslide susceptibility and factor effect analysis. Environmental Geology 47: 982-990.

Lin, Y.P., Chu, H.J. \& Wu, C.F. 2010. Spatial pattern analysis of landslide using landscape metrics and logistic regression: A case study in Central Taiwan. Hydrology and Earth System Sciences Discussions 7: 3423-3451.

Matthew, J., Jha, V.K. \& Rawat, G.S. 2007. Application of binary logistic regression analysis and its validation for landslide susceptibility mapping in part of Garhwal Himalaya, India. International Journal of Remote Sensing 28(10): 2257-2275.

Melchiorre, C., Matteucci, M., Azzoni, A. \& Zanchi, A. 2008. Artificial neural networks and cluster analysis in landslide susceptibility zonation. Geomorphology 94: 379-400.

Peralvarez, J.D.J., Irigaray, C., Hamdouni, R.E. \& Chacon, J. 2009. Building models for automatic landslidesusceptibility analysis, mapping and validation in ArcGIS. Natural Hazards 50: 571-590.

Poudyal, C.P., Chang, C., Oh, H.J. \& Lee, S. 2010. Landslide susceptibility maps comparing frequency ratio and artificial neural networks: a case study from the Nepal, Himalaya. Environ. Earth Sciences 61: 1049-1064.

Rafek, A.G., Goh, T.L. \& Ariffin, M.H. 2012. Correlation of joint roughness coefficient with peak friction angles of discontinuity planes of schists, Peninsular Malaysia. Sains Malaysiana 41(3): 293-297.

Rib, H.T. \& Ta, L. 1978. Recognition and identification. In Landslides Analysis and Control, Special Report 176, edited by Schuster, R.A. Washington: National Academy of Science.

Roslee, R., Tahir, S. \& Omang, A.K.S. 2006. Engineering geology of the Kota Kinabalu area, Sabah, Malaysia. Geological Society of Malaysia Bulletin 52: 17- 25.

Saaty, T.L. 2008. Decision making with the analytic hierarchy process. International Journal of Services Sciences 1(1): 83-98.

Saaty, T. 1994. How to make a decision: The analytic hierarchy process. European Journal of Operational Research 48: 9-26.
Tongkul, F. 2007. Geological inputs in road design \& construction in mountainous areas of West Sabah, Malaysia. In Proceedings of the 2nd Malaysia-Japan Symposium on Geohazards \& Geoenvironmental Engineering, Bangi: Institute for Environment \& Development (LESTARI). pp. 39-43.

van Westen, C.J. \& Soeters, R. 1996. GISSIZ: Geographic Information Systems in Slope Instability Zonation Part 1: Theory Vol. Version 2. Enschede: ITC.

Yalcin, A. 2008. GIS based landslide susceptibility mapping using analytical hierarchy process and bivariate statistics in Ardesen (Turkey): Comparisons of results and confirmations. Catena 72: 1-12.

Yang, S.R. \& Yeh, Y.L. 2015. Geologic hazard risk assessment of slopeland villages in Southern Taiwan using remote sensing techniques. Sains Malaysiana 44(12): 1677-1683.

Norbert Simon* \& Mairead de Roiste

Geology Program, School of Environmental \& Natural Resources Sciences

Faculty of Science and Technology

Universiti Kebangsaan Malaysia

43600 UKM Bangi, Selangor Darul Ehsan

Malaysia

Michael Crozier

School of Geography, Environment and Earth Sciences

Victoria University of Wellington

New Zealand

Abdul Ghani Rafek

Department of Geosciences

Universiti Teknologi PETRONAS, Bandar Seri Iskandar

31750 Tronoh, Perak Darul Ridzuan

Malaysia

*Corresponding author; email: norbsn@ukm.edu.my

Received: 19 November 2015

Accepted: 19 April 2016 